\title{
Veri Zarflama Analizi ile Finansal ve Operasyonel Etkinlik Ölçümü: Geleneksel Havayolu İşletmelerinde Bir Uygulama
}

\section{Analysis of Financial and Operational Efficiency with Data Envelopment Analysis: An Application in Traditional Airlines Operations}

\author{
Arș. Gör. Veysi Asker
}

Başvuru Tarihi: 10.02 .2017

Kabul Tarihi: 04.08.2017

\begin{abstract}
Öz
Teknolojinin gelişmesi ve küreleşmenin artması ile birlikte hava taşımacıllğı sektörü yoğun olarak kullanılmaya başlanmıştır. Ancak havayolu işletmeleri için hayati öneme sahip olan uçak kiralama, alım ve bakım gibi maliyetlerin büyük yatırımlar gerektirmesi işletme ortaklarmin ve yöneticilerinin daha dikkatli davranmalarını gerektirmektedir. Bu açıdan hava taşımacılığı ile ilgili faaliyetlerin gerçekleştirilmesi, geliştirilmesi yolcu ve yük talebinin doğru ve eksiksiz bir şekilde tahmin edilmeye çalışılması ve işletme kârllilğının arttırılması işletme yöneticilerinin en önemli görevidir. Son yıllarda havacılik alanında yaşanan serbestleşme hareketleri ve yapilan düzenlemelerle birlikte hava taşımacıllğı sektöründe faaliyet gösteren işletmelerin artan rekabet koşullarına ayak uydurmalarını ve sürekli kendilerini yenilemelerini gerektirmektedir.
\end{abstract}

Bu çalışmanin amacı petrol fiyatlarının en yüksek seviyeye ulaştığı 2012 yılından sonra dünyanın farklı yerlerinde faaliyet gösteren 16 geleneksel havayolu işletmesinin etkinliğinin analiz edilmesidir. Çalışmada yöntem olarak veri zarflama analizi tekniği kullanılmıştır. Analiz aşamasında ASK, koltuk kapasitesi, çalışan sayısı ve yakıt giderleri girdi değişkenleri olarak kullanılmıştır. Çıktı değişkeni olarak ise RPK, doluluk oranı ve toplam taşınan yolcu sayısı kullanılmıştır. Ça- lı̧̧manın bulguları, birçok havayolu işletmesinin ilgili dönemde CCR modeline göre etkin çıkmadiğını ancak girdi ve çıktı odaklı BCC modeline göre ise etkin çıktığını göstermektedir.

Anahtar Kelimeler: Etkinlik, Verimlilik, VZA, Havayolu

\begin{abstract}
With the development of technology and the increasing of globalization, the air transportation sector has started to be used extensively. However, leasing, purchasing and maintenance of aircraft, which have vital importance for airline operators require large investments. This situation leads business partners and managers to be more cautious. In this respect, The most important duties of airline managers are to carry out the activities related to the air transportation, to try to estimate the passenger and freight demand accurately and completely and to increase the profitability of the enterprise. In recent years, along with the liberalization movements in the field of aviation and the arrangements made, the air transportation sector has turned into a sector where competition is more intense. This situation requires
\end{abstract}

Arş. Gör. Veysi Asker, Anadolu Üniversitesi Havacılık ve Uzay Bilimleri Fakültesi, veysi-asker@outlook.com 
companies operating in the air transport sector to keep up with the increasingly competitive conditions and constantly renew themselves.

The aim of this study is to analyze the effectiveness of 16 traditional airline operations operating in different parts of the world since 2012 when oil prices reached the highest level. Data envelopment analysis technique was used as a method in the study. Input variables such as ASK (Available Seat Kilometer), seat capacity, number of employees and fuel consumption are used during the analysis phase. Output variables are RPK (Revenue Passenger Kilometer), Load Factor and total number of passengers. Findings of the study show that most airline operations are not active according to the CCR model in the period concerned but active output according to the input and output-oriented BCC model.

\section{Keywords: Efficiency, Productivity, DEA, Airline}

\section{Giriş}

Dünya' da ve ülkemizde teknolojinin gelişmesi ve küreselleşmenin hızlanması ile beraber hava taşımacılığ1 sektörü büyüyüp gelişmiştir. Hava taşımacıllğı sektörünün en önemli unsurlarından biri olan havayolu işletmelerinin artan rekabet ortamına ayak uydurabilmeleri ve rakip işletmelerle kendilerini karşılaştırabilmeleri için etkinlik ölçümüne ihtiyaç duymuşlardır. Havayolu işletmelerinin etkin olup olmadıkları sorusunun cevabını aramak için veri zarflama analizi tekniği kullanılarak yapılmış olan birçok çalışma bulunmaktadır. Bu çalışmaların birçoğunda genel olarak havayolu işletmelerinin hem operasyonel etkinliği hem de finansal etkinliği ölçülmeye çalışılmıştır.

Havayolu işletmeleri yakıt fiyatlarındaki dalgalanmalardan etkilenmemek için hedging yöntemini kullanmaktadırlar. Hedging yöntemi, gelecekte yaşanacak olan fiyat dalgalanmalarının yol açtığı zarar riskini azaltmak için kullanılan bir yöntemdir. Havayolu işletmeleri hedging yöntemi sayesinde ileri bir tarihte satın alacakları yakıt miktarından dolayı yapacakları ödemeleri sabitleyebilmektedirler. Yakıt giderinin havayolu işletme giderleri içerisinde önemli bir paya sahip olmasından dolayı hedging anlaşmaları havayolu işletmelerinin verimliliğini doğrudan etkilemektedir.
$\mathrm{Bu}$ çalışmada literatürde yer alan diğer çalışmalardan farklı olarak petrol fiyatlarının en yüksek seviyeye ulaştığı 2012 yılından sonraki dönem incelenmiştir. Bunun temel nedeni havayollarının petrol fiyatlarına verdikleri tepkilerin performans üzerindeki etkisinin tespit edilmesidir. Çalışmanın devamında alan yazında yapılmış çalışmalara yer verilecektir.

Schefczyk, Dünyanın Farklı yerlerinde faaliyet gösteren 15 havayolu işletmesinin operasyonel performansını veri zarflama analizi ile ölçmek için mevcut-ton $\mathrm{km}$, çalışan sayısı, dönen varlıklar, yakıt maliyeti, personel giderleri, diğer varlıklar ve diğer giderler gibi değişkenleri girdi olarak ele almıştır. Yolcu ve kargo gelirleri ile diğer gelirler ise çıktı olarak ele almıştır. Analiz sonucunda yüksek performansa sahip işletmelerin yüksek kârlılığa sahip olduğu belirtilmiştir. Analize dâhil olan havayolu işletmelerinin büyük bir kısmın temel faaliyet alanlarına odaklanarak etkinliğe ulaşabileceği tespit edilmiştir (Schefczyk, 1993).

Yapılan bir diğer çalışmada Good vd., Amerika’nın en büyük 8 havayolu işletmesi ile Avrupa'nın en büyük 8 havayolu işletmesinin finansal ve operasyonel etkinliğini veri zarflama analizi tekniği aracıllğıyla ölçmek için girdi olarak çalışan sayısı ile uçuş ekipman sayısını baz almış, çıktı olarak ise toplam geliri baz almıştır. Analiz sonucunda Avrupa'daki ve Amerika'daki havayolu işletmelerinin 1978 yılında yapılan serbestleşme ilgili düzenlemelerden olumlu olarak etkilendikleri ancak Avrupa'daki havayolu işletmeleri için gerekli olan düzenlemelerin daha da geliştirilmesi gerektiğinden söz edilmiştir (Good vd., 1995).

Yapılan bazı çalışmalarda ise etkinlik ölçümünde veri zarflama analizinin yanı sıra toplam faktör verimliliği ile regresyon analizi gibi yöntemler de kullanılmıştır. Örneğin Alam ve Sickles, Amerika'da bulunan 11 havayolu işletmesinin borsa getirileri ile teknik verimlilik arasındaki ilişkiyi veri zarflama analizi tekniği ile serbest atılabilir bölge analizi aracılığı ile ölçmüşlerdir. Analizde 1970-1990 yıllarına ait toplam uçak sayısı, toplam çalışan sayısı, toplam yakıt miktarı ile diğer giderler girdi olarak ele alınmış, çıktı olarak ise toplam kargo ve yolcu gelirleri ele alınmıştır. Analiz sonucunda ilgili havayolu işletmelerinin teknik verimlilikleri ile borsa hareketleri arasında güçlü bir ilişkinin bulunduğu diğer bir değişle firma değerlemesi ile firma kaynaklarının ne kadar verimli kullanıldığ 1 arasında güçlü bir bağ olduğu tespit edilmiştir (Alam ve Sıckles, 1998). 
Benzer bir çalışmada ise Scheraga, Avrupada, Asya'da, Kuzey Amerika'da ve Ortadoğu'da faaliyet gösteren 38 havayolu işletmesinin 2000 yllındaki etkinliğini veri zarflama analizi ve tobit regresyon modeli ile ölçmek amaciyla mevcut ton kilometre, faaliyet giderleri, uçuşla ilgili olmayan varlıkları girdi olarak ele almıştır. Toplam kargo ve yolcu gelirlerini ise çıtı olarak ele almıştır. Analiz sonucunda son yillarda havayolu endüstri yapısının değişmekte olduğu ve bu durumun da ücretler üzerinde aşağı yönlü bir baskı oluşturabileceği belirtilmiş ve böyle bir ortamda havayolu işletmelerinin markalaşma açısından zorluk yaşayacağından bahsedilmiştir (Scheraga, 2004).

Benzer şekilde yapılan bir diğer çalışmada Saranga ve Nagpal Hindistan'da bulunan 13 havayolu işletmesinin 2005-2012 yılları arasındaki etkinliğini veri zarflama analizi tekniği ve regresyon modeli ile ölçmüştür. Analizde girdi olarak personel sayısı, ASK, faaliyet ve personel giderleri kullanılmış çıktı olarak ise RPK ile faaliyet gelirleri kullanılmıştır. Analiz sonucunda Hindistan'da bulunan düșük maliyetli havayolu işletmelerinin operasyonel verimliklerinin iyi durumda olduğu tespit edilmiştir. Hindistan'da bulu- nan havayolu işletmelerinin öncelikli olarak yapısal düzenlemelere dikkat etmesi gerektiği vurgulanmış ve operasyon stratejisinin seçilen rekabet stratejisi ile uyumlu bir hale getirilmesi gerektiğinden bahsedilmiştir (Saranga ve Nagpal, 2016).

See ve Rashid Malezya Havayolu işletmesinin 19802013 yılları arasındaki gelişimini toplam faktör verimliliği ve tornqvist indeksi metodu ile analiz etmeye çalışmıştır. Çalışmada personel sayısı ve personel giderleri, yakıt miktarı ve gideri ile diğer giderler girdi olarak ele alınmış taşınan yolcu sayısı, taşınan yük miktarı ile havacılık dışı gelirler çıktı olarak ele alınmıştır. Analiz sonucunda Malezya Havayolu işletmesinin yıllara göre yavaş bir büyüme gösterdiği, yaşlanan uçaklarla birlikte bakım masrafları ve uçak kiralama tutarlarının arttığı tespit edilmiştir. Bununla birlikte uçakların daha etkin ve verimli kullanılması gerektiği belirlenmiştir. Malezya'daki hava taşımacılığ1 sektöründe rekabete aykırı politikaların bulunmasından dolayı Malezya Havayolu işletmesinin olumsuz etkilendiğinden bahsedilmiştir (See ve Rashid, 2016). VZA ile ilgili yapılmış diğer çalışmalar aşağıda Tablo 1'de verilmiştir:

Tablo 1. Havayolu işletmelerinde Performans Ölçümü Üzerine Yapılmış Çalışmalar

\begin{tabular}{|c|c|c|c|c|}
\hline Yazar / Yıl & Örneklem / Yll & Yöntem & Girdi & Çıktı \\
\hline Cao vd. (2015) & $\begin{array}{l}29 \text { havayolu/ } \\
2005-2009\end{array}$ & $\begin{array}{lr}\text { Veri Zarflama } \\
\text { Analizi } \\
\text { Toplam } \quad \text { Faktör } \\
\text { Verimliliği }\end{array}$ & $\begin{array}{l}\text { Çalışan Sayısı } \\
\text { Toplam Uçak Sayısı } \\
\text { Toplam Yakıt Miktarı }\end{array}$ & $\begin{array}{l}\text { Toplam Uçuş Sayısı } \\
\text { RTK( Kilometre } \\
\text { Başına Ton Geliri) } \\
\text { RPK(Kilometre } \\
\text { Başına Yolcu } \\
\text { Gelirleri) }\end{array}$ \\
\hline Mallikarjun (2015) & $\begin{array}{l}27 \text { havayolu / } \\
2012\end{array}$ & $\begin{array}{l}\text { Veri Zarflama } \\
\text { Analizi }\end{array}$ & $\begin{array}{l}\text { Faaliyet Giderleri } \\
\text { ASM( Arz Edilen } \\
\text { Yolcu Mil) }\end{array}$ & $\begin{array}{l}\text { Faaliyet Gelirleri } \\
\text { RPM( Mil Başına } \\
\text { Yolcu Geliri) }\end{array}$ \\
\hline $\begin{array}{l}\text { Lee ve Worthington } \\
/ 2014\end{array}$ & $\begin{array}{l}42 \text { Havayolu / } \\
2006\end{array}$ & $\begin{array}{l}\text { Veri Zarflama } \\
\text { Analizi ile Sınır } \\
\text { Etkinliği Analizi }\end{array}$ & $\begin{array}{l}\text { Çalışan Sayısı } \\
\text { Toplam Aktifler }\end{array}$ & $\begin{array}{l}\text { ATK(Arz Edilen } \\
\text { Ton Kilometre) }\end{array}$ \\
\hline Tavassoli vd. 2014 & $\begin{array}{l}11 \text { Havayolu/ } \\
2010\end{array}$ & $\begin{array}{l}\text { Serbest Tabanlı } \\
\text { Veri Zarflama } \\
\text { Analizi modeli }\end{array}$ & $\begin{array}{l}\text { Toplam Uçak Sayısı } \\
\text { Çalışan Sayısı }\end{array}$ & ATK \\
\hline $\begin{array}{l}\text { Arjomandi ve Seufert } \\
\text { (2014) }\end{array}$ & $\begin{array}{l}48 \text { havayolu/ } \\
2007-2010\end{array}$ & $\begin{array}{l}\text { Veri Zarflama } \\
\text { Analizi }\end{array}$ & $\begin{array}{l}\text { Çalışan Sayısı } \\
\text { Toplam Uçuş Saati }\end{array}$ & $\begin{array}{l}\text { ATK } \\
\mathrm{Co}_{2} \text { Emisyon }\end{array}$ \\
\hline
\end{tabular}


Tablo 1. Havayolu işletmelerinde Performans ölçümü Üzerine Yapılmış Çalışmalar (Devamı)

\begin{tabular}{|c|c|c|c|c|}
\hline Wu ve Diğerleri/ 2013 & $\begin{array}{l}12 \text { Havayolu } \\
\text { /2006 }\end{array}$ & $\begin{array}{l}\text { Veri Zarflama } \\
\text { Analizi modeli }\end{array}$ & $\begin{array}{l}\text { Çalışan Sayısı } \\
\text { Faaliyet Giderleri } \\
\text { Toplam Uçak Sayısı }\end{array}$ & $\begin{array}{l}\text { RTK } \\
\text { Faaliyet Gelirleri }\end{array}$ \\
\hline Barros vd. /2013 & $\begin{array}{l}11 \quad \text { Havayolu/ } \\
1998-2010\end{array}$ & $\begin{array}{l}\text { Veri Zarflama } \\
\text { Analizi modeli }\end{array}$ & $\begin{array}{l}\text { Çalışan Sayısı } \\
\text { Toplam Yakıt Miktarı } \\
\text { Toplam Maliyet }\end{array}$ & $\begin{array}{l}\text { Toplam Gelir } \\
\text { RPM } \\
\text { Doluluk Oranı }\end{array}$ \\
\hline Gramani (2012) & $\begin{array}{l}34 \text { Havayolu } \\
1997-2006\end{array}$ & $\begin{array}{l}\text { Veri Zarflama } \\
\text { Analizi }\end{array}$ & $\begin{array}{l}\text { Yakıt maliyeti } \\
\text { Personel Gideri } \\
\text { Koltuk- mil başına } \\
\text { maliyet }\end{array}$ & $\begin{array}{l}\text { Yolcu başına gelir } \\
\text { Toplam gelir }\end{array}$ \\
\hline Lu vd. (2012) & $\begin{array}{l}30 \quad \text { Havayolu/ } \\
2010\end{array}$ & $\begin{array}{l}\text { Veri Zarflama } \\
\text { Analizi }\end{array}$ & $\begin{array}{l}\text { Yakıt maliyeti } \\
\text { Personel Gideri } \\
\text { Toplam Koltuk sayısı } \\
\text { Bakım giderleri }\end{array}$ & $\begin{array}{l}\text { RPM } \\
\text { Diğer giderler }\end{array}$ \\
\hline $\begin{array}{l}\text { Merkert ve Hensher } \\
\text { /2011 }\end{array}$ & $\begin{array}{l}58 \quad \text { Havayolu/ } \\
2007-2009\end{array}$ & $\begin{array}{l}\text { Veri Zarflama } \\
\text { Analizi ve Tobit } \\
\text { Model }\end{array}$ & $\begin{array}{l}\text { Çalışan Sayısı } \\
\text { Personel Gideri } \\
\text { ATK } \\
\text { ATK Gideri }\end{array}$ & $\begin{array}{l}\text { RPK } \\
\text { RTK }\end{array}$ \\
\hline Wang vd.(2011) & $\begin{array}{l}30 \quad \text { havayolu } \\
/ 2006\end{array}$ & $\begin{array}{l}\text { Veri Zarflama } \\
\text { Analizi }\end{array}$ & $\begin{array}{l}\text { Çalışan Sayısı } \\
\text { Yakıt maliyeti } \\
\text { Uçak Sayısı }\end{array}$ & $\begin{array}{l}\text { ASK } \\
\text { RPK } \\
\text { Diğer gelirler }\end{array}$ \\
\hline Zhu vd.(2011) & $\begin{array}{l}21 \quad \text { Havayolu } \\
/ 2007-2008\end{array}$ & $\begin{array}{l}\text { Veri Zarflama } \\
\text { Analizi }\end{array}$ & $\begin{array}{l}\text { Yakıt maliyeti } \\
\text { Personel Gideri } \\
\text { Koltuk- mil başına } \\
\text { maliyet }\end{array}$ & $\begin{array}{l}\text { RPM } \\
\text { Doluluk Oranı }\end{array}$ \\
\hline Hong ve Zhang (2010) & $\begin{array}{l}29 \text { havayolu } \\
/ 1998-2002\end{array}$ & $\begin{array}{l}\text { Veri Zarflama } \\
\text { Analizi }\end{array}$ & $\begin{array}{l}\text { ASM } \\
\text { Çalışan sayısı }\end{array}$ & $\begin{array}{l}\text { Toplam gelir } \\
\text { RPK } \\
\text { RTK }\end{array}$ \\
\hline Chow (2010) & $\begin{array}{l}17 \quad \text { Havayolu/ } \\
1980-2007\end{array}$ & $\begin{array}{lr}\text { Veri Zarflama } \\
\text { Analizi r ve } \\
\text { Toplam Faktör } \\
\text { Verimliliği }\end{array}$ & $\begin{array}{l}\text { Yakıt maliyeti } \\
\text { Personel Gideri } \\
\text { Toplam Koltuk Sayısı }\end{array}$ & $\begin{array}{l}\text { RPK } \\
\text { RTK }\end{array}$ \\
\hline $\begin{array}{l}\text { Barros Ve Paypoch } \\
(2009)\end{array}$ & $\begin{array}{l}27 \quad \text { Havayolu } \\
/ 2000-2005\end{array}$ & $\begin{array}{l}\text { Veri Zarflama } \\
\text { Analizi ve } \\
\text { Regresyon } \\
\text { Analizi }\end{array}$ & $\begin{array}{l}\text { Çalışan Sayısı } \\
\text { Faaliyet Giderleri }\end{array}$ & $\begin{array}{l}\text { RPK } \\
\text { FVÖK( Faiz ve } \\
\text { Vergi Öncesi Kâr) }\end{array}$ \\
\hline
\end{tabular}


Tablo 1. Havayolu işletmelerinde Performans ölçümü̈ Üzerine Yapılmış Çalışmalar (Devamı)

\begin{tabular}{|c|c|c|c|c|}
\hline Bhadra (2009) & $\begin{array}{l}13 \text { Havayolu } \\
/ 1985-2006\end{array}$ & $\begin{array}{l}\text { Veri Zarflama } \\
\text { Analizi }\end{array}$ & $\begin{array}{l}\text { Çalışan Sayısı } \\
\text { Yakıt Maliyeti } \\
\text { Uçak başına Koltuk } \\
\text { sayısı } \\
\text { Uçak kullanım Oranı } \\
\text { Uçak sayısı }\end{array}$ & $\begin{array}{l}\text { ASM( Arz Edilen } \\
\text { Koltuk Mil) }\end{array}$ \\
\hline Greeer (2009) & $\begin{array}{l}17 \quad \text { Havayolu/ } \\
1999-2008\end{array}$ & $\begin{array}{l}\text { Veri Zarflama } \\
\text { Analizi ve Tobit } \\
\text { Regresyon } \\
\text { Analizi }\end{array}$ & $\begin{array}{l}\text { Koltuk kapasitesi } \\
\text { Yakıt maliyeti } \\
\text { Çalışan Sayısı }\end{array}$ & ASM \\
\hline Barbot vd./ 2008 & $\begin{array}{ll}49 & \text { Havayolu/ } \\
2005 & \end{array}$ & & $\begin{array}{l}\text { Çalışan Sayısı } \\
\text { Yakıt Maliyeti } \\
\text { Diğer Giderler } \\
\text { Sermaye Maliyeti }\end{array}$ & Toplam Gelir \\
\hline Greer / 2008 & $\begin{array}{l}8 \quad \text { Havayolu/ } \\
2000-2004\end{array}$ & $\begin{array}{lr}\text { Veri Zarflama } \\
\text { Analizi r ve } \\
\text { Toplam Faktör } \\
\text { Verimliliği }\end{array}$ & $\begin{array}{l}\text { Çalışan Sayısı } \\
\text { Yakıt Maliyeti } \\
\text { Koltuk Kapasitesi }\end{array}$ & ASM \\
\hline Chiou ve Chen / 2006 & $\begin{array}{l}15 \text { Havayolu } \\
\text { Güzergâhı }\end{array}$ & $\begin{array}{l}\text { Veri Zarflama } \\
\text { Analizi ve Tobit } \\
\text { Regresyon } \\
\text { Modeli }\end{array}$ & $\begin{array}{l}\text { Yakıt Maliyeti } \\
\text { Personel Maliyeti } \\
\text { Uçakla İlgili } \\
\text { Maliyetler }\end{array}$ & $\begin{array}{l}\text { Uçuş Sayısı } \\
\text { ASM } \\
\text { Uçan Yolcu Sayısı }\end{array}$ \\
\hline
\end{tabular}

\section{Veri Zarflama Analizi Yöntemi}

Veri zarflama analizi, her bir karar verme biriminin göreceli olarak etkinliğini değerlendirebilmek için çok sayıda girdi ve çıtının kullanıldığı bir analiz çeşididir (Lang vd., 1995, s. 473). Veri zarflama analizi, homojen olduğu kabul edilen üretim faktörlerinin karşılaştırılması sonucunda elde edilen en iyi gözlem değerini etkinlik sınırı kabul ederek elde edilen diğer gözlemleri bu en iyi gözleme göre değerlendirmektir (Seyrek ve Ata, 2010, s. 70). Bir diğer tanıma göre ise veri zarflama analizi, farklı birimlere ait birden fazla girdi ve çıktının olduğu ve bu girdi ve çıktıların ortak bir ölçütte değerlendirilemediği durumlarda göreceli toplam faktör etkinliğini ölçebilme olanağı sunan, üretim ekonomisine uyumlu bir yöntemdir (Güran ve Cingi, 2002, s. 64).
Veri zarflama analizi birden çok girdi ve çıtıyı nicel bir etkinlik kıstasına dönüştürebilen matematiksel programlama tabanlı bir analizdir. Analizin en temel özelliği benzer özelliklere sahip karar unsurlarının üretim aşamasındaki etkinliklerinin değerlendirilmesidir. Analize konu olan karar birimlerinin benzer amaçlara yönelik aynı işlevi görmesi, aynı piyasa şartlarında faaliyet göstermesi ve grup içerisindeki tüm değişkenlerin verimliliklerini açıklayan faktörlerin büyüklük miktarlarındaki farklılıklar dışında birbirine çok yakın olması beklenir (Karsak ve İşcan, 2000, s. 3).

Veri zarflama analizi matematiksel programlama teorisini temel alan karar verme unsurlarının göreceli verimliliği hakkında fikir yürütebilmek için oluştu- 
rulmuş ve parametrik özelliği olmayan bir analiz yöntemidir (Kutlar ve Kartal, 2004, s. 53). Bunun yanında veri zarflama analizindeki temel beklenti, tüm karar verme birimlerinin ayn stratejik hedeflere sahip olması ve aynı türden girdi kullanılarak aynı türden çıtı elde edilmesidir (Golany ve Roll, 1989, s. 237).

Etkinlik analizindeki engelleri ortadan kaldırmak için geliştirilmiş bir yöntem olan veri zarflama analizi ilk dönemlerde kâr amacı olmayan kuruluşların etkinliklerinin ölçümünde kullanılmıştır. Daha sonraki yıllarda ise kâr amacı ile çalışan üretim sektörlerinde kullanılmaya başlanmıştır (Yolalan, 1993, s. 27). Bununla birlikte günümüzde alan yazına bakıldığında veri zarflama analizinin bankalar, oteller, sigorta şirketleri, hastaneler, imalathaneler gibi birçok yerde kullanıldığ görülmektedir. Analizin uygulama aşamasında ise ilgili kuruluşlar, faaliyette bulundukları sektör içerisindeki diğer kuruluşlarla karşılaştırılarak göreceli verimlilikleri tespit edilmeye çalışılmaktadır (Tetik, 2003, s. 222).
Veri zarflama analizinde ilk kullanılan ve "ölçeğe göre sabit getiri” varsayımına dayanan CCR modeli ilk olarak kamu sektöründe verimlilik ölçümü amacı ile kullanılmış, sonraki dönemlerde ise birbirinden farklı alanlarda kullanılmaya başlanmıştır. Veri zarflama analizinde kullanılan bir değer yöntem "ölçeğe göre değişken getiri” varsayımına dayanan BCC modelidir. Bu model ilk olarak 1984 yılında kullanıldıktan sonra birçok farklı sektörde uygulama alanı bulmuştur (Coelli vd., 2005, s. 162).

Veri zarflama analizinde kullanılan modeller, birbirinden farklı kriterlerin baz alınması ile kendi içerisinde farklı şekillerde sınıflandırılabilmektedir. İlk ortaya çıktığı dönemlerde "ölçeğe göre sabit getiri" varsayımına dayanan CCR modelleri kullanılmıştır. Daha sonra "ölçeğe göre değişken getiri” varsayımına dayanan BCC modelleri kullanılmıştır. Bununla birlikte veri zarflama analizi tekniğinin geliştirilmesi ile günümüzde birçok farklı model ve farklı sınıflandırma şekilleri bulunmaktadır (Lovell ve Pastor, 1997, s. 291). Tablo 2'de söz konusu modeller görülmektedir.

Tablo 2. Veri Zarflama Analizi Modelleri

\begin{tabular}{l|l|l}
\multicolumn{1}{l}{ Uygulanan Model } & Kabul Edilen Varsayım & Yönelim Durumu \\
\hline CCR & Ölçeğe Göre Sabit Getiri & Girdi ve Çıktı yönlü \\
\hline BCC & Ölçeğe göre Değişken Getiri & Girdi ve Çıktı yönlü \\
\hline \multicolumn{2}{l}{ Kaynak: A.Y. Lewin, L.M Seiford Extending The Frontiers of DEA, Annals of operations Research, Vol: 73, 1ssue: 1,1997, s.2 }
\end{tabular}

\section{CCR (Charnes, Cooper, Rhodes) Modeli}

1978 yilında ilk defa Charnes, Cooper ve Rhodes'un oluşturmuş olduğu CCR modeli ölçeğe göre sabit getiri varsayımına dayanmaktadır. Model adını modeli oluşturan kişilerin baş harflerinden (CCR) almaktadır. Bununla birlikte CCR modeli aracılı̆̆ı ile karar verme birimlerinin toplam etkinlikleri ölçülebilmekte ve karar verme birimlerinin CCR modelinde etkin olabilmesi için hem teknik açıdan hem de ölçek açısindan etkin olması gerekmektedir. (Lorcu, 2008, s. 71).

\section{Çıktıya Yönelik CCR Modeli}

Girdi miktarını değiştirmeden, mevcut girdiler ile karar verme birimini etkin hale getirmek için analiz sonucunda elde edilen çıtıların hangi oranda arttırıl- ması gerektiğini gösteren çıktıya yönelik bir modeldir (Matthews ve Ismail, 2006, s. 7). Çıktıya yönelik CCR modelinin matematiksel gösterimi aşağıda verilmiştir (Cooper, Seiford, \& Tone, 2006, s. 61):

$$
Q_{k}=\max \left(\theta+\varepsilon \sum_{i=1}^{m} S_{i}^{-}+\varepsilon \sum_{r=1}^{s} S_{r}^{+}\right)
$$

\section{Kisitlar,}

$$
\begin{aligned}
& \sum_{j=1}^{n} X_{i j} \beta_{j}+S_{i}^{-}-X_{i k}=0 \quad i=1, \ldots \ldots m \\
& \sum_{j=1}^{n} Y_{r j} \beta_{j}-S_{i}^{-}-\beta Y_{k}=0 \quad r=1, \ldots . p \quad j=1, \ldots n \quad i=1, \ldots . m \\
& \beta_{j} \geq 0 \quad S_{i}^{-} \geq 0 \quad S_{r}^{+} \geq 0
\end{aligned}
$$


Modelde,

$\theta$ : Göreceli etkinliği ölçülmüş olan karar verme birimine ait çıktı miktarının ne kadar arttırması gerektiğini belirleyen genişleme katsayısı,

$\beta_{\mathrm{j}}$ : Çıktı odaklı modellerde j’ye ait karar biriminin almiş olduğu yoğunluk değeri,

\section{BCC (Banker, Charnes, Cooper) Modeli}

1984 yllında ilk defa Banker, Charnes ve Cooper'in oluşturmuş olduğu BCC modeli ölçeğe göre değişken getiri varsayımına dayanmaktadır. Model adını modeli oluşturan kişilerin baş harflerinden (BCC) almaktadır. BCC modelleri CCR modellerinden farklı olarak belirli bir ölçekte üretim yapan karar verme unsurlarının etkinliğini değişken getiri varsayımına dayanarak ölçmektedir ( (İşbilen Yücel, 2010, s. 71).

\section{Girdiye yönelik BCC modeli}

Girdi odaklı BCC modelleri belirli bir çıktı kümesini en etkin bir şekilde elde edebilmek için kullanılması gereken en uygun girdi kümesinin ne şekilde oluşturulması gerektiğini gösteren modellerdir (Kazançoğlu, 2008, s. 151). Girdi odaklı BCC modelinin matematiksel gösterimi aşağıda verilmiştir (Banker vd., 2004, s. 346):

$$
Q_{k}=\operatorname{Min}\left(\theta-\varepsilon \sum_{i=i}^{m} S_{i}^{-}-\varepsilon \sum_{r=1}^{p} S_{r}^{+}\right)
$$

Kisitlar,

$$
\begin{aligned}
& \sum_{j=1}^{n} X_{i j} \beta_{j}+S_{i}^{-}-\theta X_{i k}=0 \quad i=1,2, \ldots m \\
& \sum_{j=1}^{n} X_{i j} \beta_{j}-S_{i}^{+}-Y_{r k}=0 \quad r=1,2, \ldots p \\
& \sum_{j=1}^{n} \beta_{j}=1 \quad \beta_{j} \geq 0 \quad S_{i}^{-} \geq 0 \quad S_{i}^{+} \geq 0 \quad j=1,2, \ldots n \\
& i=1,2 \ldots . m \quad r=1,2, \ldots . p
\end{aligned}
$$

\section{Ç1ktıya Yönelik BCC Modeli}

Çıktıya yönelik BCC modelinde, çıktıya yönelik CCR modelinde olduğu gibi belirli bir girdi değişkeninden oluşan girdi kümenin en verimli bir şekilde kullanıl- ması ile en çok ne kadar çıktı miktarı elde edilebileceği araştırılmaktadır (Cooper vd., 2006, s. 89). Çıktıya yönelik BCC modelinin matematiksel gösterimi şu şekildedir (Chen ve Ali, 2002, s. 477):

$$
E_{o}=\operatorname{Max}\left(\theta+\varepsilon \sum_{i=i}^{m} S_{i}^{-}+\varepsilon \sum_{r=1}^{p} S_{r}^{+}\right)
$$

Kisitlar,

$$
\begin{aligned}
& \sum_{j=1}^{n} X_{i j} \beta_{j}+S_{i}^{-}-X_{i k}=0 \quad i=1,2, \ldots m \\
& \sum_{j=1}^{n} y_{r j} \beta_{j}-\theta Y_{r k}-S_{r}^{+}=0 \quad r=1,2, \ldots p \\
& \sum_{j=1}^{n} \beta_{j}=1 \quad \beta_{j} \geq 0 \quad S_{i}^{-} \geq 0 \quad S_{i}^{+} \geq 0 \quad j=1,2, \ldots n \\
& i=1,2 \ldots . m \quad r=1,2, \ldots . p
\end{aligned}
$$

\section{Uygulama}

Son zamanlarda etkinlik ölçümünde yaygın bir şekilde kullanılmaya başlanan veri zarflama analizinin ilk aşaması karar verme birimlerinin tespit edilmesidir. Karar verme birimlerinin homojen özellik taşıması analiz sonucunda ortaya çıkacak sonuçların güvenilir olması açısından büyük önem taşımaktadır. Karar verme birimlerinin homojen özellik taşıması aynı girdi-çıktı kümelerine sahip oldukları anlamına gelmektedir. Karar verme birimi sayısının artması ile birlikte homojen yapı bozulabilmektedir (Yolalan, 1993, s. 89). Bu açıdan analize dâhil olan havayolu işletmelerinin bulundukları ülkelerde bayrak taşıyıcı olmaları ve geleneksel havayolu özelliği taşımalarından dolayı benzer özellikler göstermektedirler.

Veri zarflama analizi tekniğinde karar verme biriminin seçimi ile ilgili iki farklı görüş bulunmaktadır. İlk görüşe göre karar verme birimi sayısının girdi ve çıktı sayısının en az iki katı olması gerekmektedir (Dyson vd., 2001, s. 247). İkinci görüşe göre ise karar verme birimi sayısının girdi ve çıktı sayısının çarpımına eşit olması veya karar verme birimi sayısının girdi ve çıktı sayısının minimum üç katı olması gerekmektedir (Cooper, vd., 2001, s. 219). Alan yazında yapilan çalışmaların birçoğunun birinci görüşü esas aldığ1 
tespit edilmiş ve bu çalışmada da birinci görüş doğrultusunda karar verme birimi sayısı ile girdi-çıtktı değişkeni sayısı belirlenmiştir.

Araştırmaya dünyanın farklı yerlerinde faaliyet gösteren ve bulundukları ülkelerin bayrak taşıyıcısı olan 16 geleneksel havayolu işletmesi dâhil edilmiştir. Bununla birlikte ilgili havayolu işletmelerinin 2013 ve 2014 yıllarına ait verimlilik ve etkinlik ölçümün yapılması amaçlanmaktadır. 2013 ve 2014 yıllarının seçilmesinin amacı yakıt fiyatlarının en fazla artış kaydettiği 2012 y1lından sonra takip eden y1llarda havayolu işletmelerinin etkinlik ve verimliklerinin tespit edilmesidir. Araştırmaya dahil olan havayollarının iki tanesi Kuzey Amerika, iki tanesi Güney Amerika, iki tanesi Afrika, üç tanesi Asya, yedi tanesi ise Avrupa merkezli havayolu işletmeleridir. İlgili havayolu işletmelerinden Aegean Havayolları, Air Canada, All Nippon Havayolları, Avusturya, Avianca, Hırvatistan, Mısır, Güney Afrika ve Türk Havayolları Star Alliance işbirliğine üyedir. Finnair, Japon Havayolları, Ürdün Kraliyet Havayolları ve Tam Havayolları ise One World işbirliğine üyedir. Bununla birlikte Aeroflot, Aeromexico, ve Kore havayolları Sky Team işbirliğine üyedir. Bu çalışmada ilgili havayolu işletmelerinin etkinlik ölçümün yapılmasının yanı sıra bu havayolu işletmelerinin bağlı bulunduğu stratejik ittifakların da kısmi olarak etkinliği ölçülmüş olacaktır.

Veri zarflama analizi ile yapılan etkinlik ölçümünde en önemli aşamalardan biri girdi ve çıktı kümesinin seçimidir. Seçilen girdi ve çıktı kümesinin kendi içerisinde tutarlı olması analizin güvenilir sonuçlar vermesini sağlamaktadır. Bu açıdan havayolu işletmelerinin verimlilik ve etkinlik ölçümünün yapıldığı çalışmalara bakıldığında genel olarak personel sayısı ve giderleri, uçak sayısı, toplam uçuş saati, faaliyet giderleri, yakıt maliyeti ve toplam maliyetler, bakım giderleri, ASK(Arz Edilen Koltuk Kilometre), ASM(Arz Edilen Koltuk Mil), toplam koltuk sayısı, uçak kullanım oranı, koltuk kapasitesi gibi verilerin girdi değişkeni olarak kullanıldığı görülmüştür (Cao vd., 2015; Lee \& Worthington, 2014; Tavassoli vd.,2014; Zhu, 2011). Toplam uçuş sayısı, RTK(Kilometre Başına Ton Geliri), RPK, faaliyet gelirleri, toplam gelir, doluluk oranı, RPM(Mil başına yolcu geliri), FVÖK(Faiz ve Vergi öncesi Kâr), uçan yolcu sayısı gibi verilerin çıktı değişkeni olarak kullanıldığı görülmüștür ( Wu vd, 2013; Barros vd., 2013; Gramani, 2012; Lu vd.,2012). Yapılan bazı çalışmalarda ise ASK, ASM ve
ATK gibi verilerin çıktı değişkeni olarak kullanıldı̆̆ 1 görülmüştür (Arjomandi \& Seufert, 2014; Merkert \& Hensher, 2011; Wang, Lu, \& Tsai, 2011).

Bu çalışmada havayolu işletmelerine ait çalışan sayıs1, ASK, yakıt gideri ve koltuk kapasitesi olmak üzere dört adet girdi değişkenine ait veriler analize dâhil edilmiştir. RPK, doluluk oranı ve taşınan yolcu sayısı ise çıktı değişkeni olarak analize dâhil edilmiștir. Analize dahil edilen çalışan sayısı havayolu işletmelerinde çalışan bireyleri kapsamaktadır. Bir diğer girdi değişkeni olan yakıt gideri ise havayolu işletmelerine ait olan uçakların kullanmış olduğu yakıt tutarını ifade etmektedir. Yakıt gideri havayolu işletmelerinin önemli giderlerinden birini oluşturmaktadır. Bir diğer girdi değişkeni olan koltuk kapasitesi ise havayolu işletmelerine ait olan uçaklarda bulunan koltuk sayısını ifade etmektedir. ASK ise havayolu işletmelerinin yolcu taşıma kapasitesinin kilometre cinsinden hesaplanmasında kullanılmaktadır. Satışa sunulan koltuk sayısının uçuş mesafesi ile çarpımı sonucunda elde edilmektedir.

Araştırmaya dâhil edilen RPK ücret karşıllı̆ında taşınan tüm yolcuların kilometre cinsinden kat ettikleri mesafeyi vermektedir. Ücret karşılığında taşınan yolcu sayısının uçuş mesafesi ile çarpımı sonucunda elde edilmektedir. Bir diğer çıtı değişkeni olan doluluk oranı ise satışa sunulmuş koltuk sayısını veya kullanılmakta olan uçak kapasitesinin hesaplanmasında kullanılmaktadır. Aşağıda gösterildiği şekilde hesaplanmaktadır (Vasıgh, Fleming, \& Tacker, 2013, s. 23):

Çalışmaya dâhil edilen girdi ve çıktı değişkenleri tespit edildikten sonra çalışan sayısı ve yakıt gideri gibi veriler ilgili havayolu işletmelerinin faaliyet raporlarından elde edilmiştir. Girdi değişkeni olarak kullanılan koltuk kapasitesi ve ASK verileri ile çıktı değişkeni olarak analize dâhil edilen RPK, doluluk oranı ile toplam taşınan yolcu sayısı ise aylık olarak yayınlanan Airline Business Dergisinden elde edilmiştir. Airline Business dergisinin ilgili havayolu işletmelerine ait verileri, Flight Global Kuruluşu tarafından temin ettiği tespit edilmiştir.

İlgili havayolu işletmelerinin verimlilik ve etkinlik ölçümünün veri zarflama analizi ile yapılabilmesi için doğrusal programlama temelli problemlerin çözümünde kullanılan Deap yazılım programı kullanılmıştır. Karar verme birimi sayısının fazla olmasından dolayı Deap programının kullanılmasına karar verilmiştir. 
Araştırmada ilgili havayolu işletmelerinin verimlilik ve etkinliklerinin ölçülmesinde ölçeğe göre sabit getiri varsayımına dayanan çıktı odaklı CCR modeli ile ölçeğe göre değişken getiri varsayımına dayanan girdi ve çıktı odaklı BCC modeli kullanılmıștır. Analiz aşa- masında ilgili havayolu işletmelerinin ilk olarak CCR modeli ile ölçek etkinliği hesaplanmıș ardından BCC modeli ile teknik etkinliği hesaplanmıștır. İlgili havayolu işletmelerinin CCR, girdi ve çıktı odaklı BCC modeline göre etkinlik değerleri Tablo 3’te verilmiștir.

Tablo 3. Analize Dâhil Olan Havayolu Işsletmelerinin CCR, Girdi Odaklı ve Çıktı Odaklı BCC Modeli ile Etkinlik Değerleri (2013)

\begin{tabular}{|c|c|c|c|}
\hline $\begin{array}{l}\text { Havayolu } \\
\text { İşletmeleri }\end{array}$ & $\begin{array}{l}\text { CCR Etkinlik Değeri } \\
\text { (Ölçek Etkinliği) }\end{array}$ & $\begin{array}{l}\text { Girdi Odaklı BCC Etkinlik } \\
\text { Değeri (Teknik Etkinlik) }\end{array}$ & $\begin{array}{l}\text { Çıktı Odaklı BCC Etkinlik } \\
\text { Değeri (Teknik Etkinlik) }\end{array}$ \\
\hline Aegean & 1.000 & 1.000 & 1.000 \\
\hline Aeroflot & 0.872 & 0.919 & 0.967 \\
\hline Aero Mexico & 0.882 & 0.906 & 0.958 \\
\hline Air Canada & 1.000 & 1.000 & 1.000 \\
\hline $\begin{array}{l}\text { All Nippon } \\
\text { Havayolları }\end{array}$ & 0.827 & 1.000 & 1.000 \\
\hline $\begin{array}{l}\text { Avusturya } \\
\text { Havayolları }\end{array}$ & 1.000 & 1.000 & 1.000 \\
\hline Avianca & 0.969 & 1.000 & 1.000 \\
\hline $\begin{array}{l}\text { Hırvatistan } \\
\text { Havayolları }\end{array}$ & 1.000 & 1.000 & 1.000 \\
\hline $\begin{array}{l}\text { Misır } \\
\text { Havayolları }\end{array}$ & 1.000 & 1.000 & 1.000 \\
\hline Finnair & 1.000 & 1.000 & 1.000 \\
\hline $\begin{array}{l}\text { Japon } \\
\text { Havayolları }\end{array}$ & 0.819 & 0.822 & 0.866 \\
\hline $\begin{array}{l}\text { Kore } \\
\text { Havayolları }\end{array}$ & 0.861 & 0.880 & 0.939 \\
\hline $\begin{array}{l}\text { Ürdün Kraliyet } \\
\text { Havayolları }\end{array}$ & 0.771 & 0.773 & 0.911 \\
\hline $\begin{array}{l}\text { Güney Afrika } \\
\text { Havayolları }\end{array}$ & 0.850 & 0.851 & 0.924 \\
\hline $\begin{array}{l}\text { Tam } \\
\text { Havayolları }\end{array}$ & 0.905 & 1.000 & 1.000 \\
\hline $\begin{array}{l}\text { Türk Hava } \\
\text { Havayolları }\end{array}$ & 0.960 & 1.000 & 1.000 \\
\hline
\end{tabular}

2013 yılında CCR modeli ile yapılan etkinlik ölçümü sonucunda 6 havayolu işletmesinin etkin çıtı̆̆ diğerlerinin ise etkin çıkmadığ 1 görülmüştür. Girdi odaklı BBC modelinde ise 10 havayolu işletmesinin etkin çıtığı tespit edilmiştir. Aynı şekilde çıktı odaklı BBC modelinde de 10 havayolu işletmesi etkin 
çıkmıştır. BCC modelinde teknik etkinliğin ölçülmesinden dolayı karar verme birimlerinin etkinlik durumları CCR modeline göre daha yüksek çıkmaktadır. BCC modeline göre etkin çıkan karar verme birimlerinin CCR modeline göre etkin çıkmamaları durumunda ilgili karar verme birimlerinin yerel olarak etkin oldukları genel olarak ise etkin olmadıkları söylenebilmektedir.

Tablo 4. Analize Dâhil Olan Havayolu İşletmelerinin CCR, Girdi Odaklı ve Çıktı Odakı BCC Modeli ile Etkinlik Değerleri (2014)

\begin{tabular}{|c|c|c|c|}
\hline $\begin{array}{l}\text { Havayolu } \\
\text { İşletmeleri }\end{array}$ & $\begin{array}{l}\text { CCR Etkinlik Değeri } \\
\text { (Ölçek Etkinliği) }\end{array}$ & $\begin{array}{l}\text { Girdi Odaklı BCC Etkinlik } \\
\text { Değeri (Teknik Etkinlik) }\end{array}$ & $\begin{array}{l}\text { Çıktı Odaklı BCC Etkinlik } \\
\text { Değeri (Teknik Etkinlik) }\end{array}$ \\
\hline Aegean & 1.000 & 1.000 & 1.000 \\
\hline Aeroflot & 0.774 & 0.888 & 0.956 \\
\hline Aero Mexico & 0.900 & 1.000 & 1.000 \\
\hline Air Canada & 0.863 & 1.000 & 1.000 \\
\hline ANA & 0.849 & 1.000 & 1.000 \\
\hline $\begin{array}{l}\text { Avusturya } \\
\text { Havayolları }\end{array}$ & 0.913 & 1.000 & 1.000 \\
\hline Avianca & 0.907 & 1.000 & 1.000 \\
\hline $\begin{array}{l}\text { Hırvatistan } \\
\text { Havayolları }\end{array}$ & 1.000 & 1.000 & 1.000 \\
\hline $\begin{array}{l}\text { Misır } \\
\text { Havayolları }\end{array}$ & 1.000 & 1.000 & 1.000 \\
\hline Finnair & 1.000 & 1.000 & 1.000 \\
\hline $\begin{array}{l}\text { Japon } \\
\text { Havayolları }\end{array}$ & 0.972 & 1.000 & 1.000 \\
\hline $\begin{array}{l}\text { Kore } \\
\text { Havayolları }\end{array}$ & 0.726 & 0.836 & 0.918 \\
\hline $\begin{array}{l}\text { Ürdün Kraliyet } \\
\text { Havayolları }\end{array}$ & 1.000 & 1.000 & 1.000 \\
\hline $\begin{array}{l}\text { Güney Afrika } \\
\text { Havayolları }\end{array}$ & 0.717 & 0.717 & 0.936 \\
\hline $\begin{array}{l}\text { Tam } \\
\text { Havayolları }\end{array}$ & 0.952 & 1.000 & 1.000 \\
\hline $\begin{array}{l}\text { Türk Hava } \\
\text { Havayolları }\end{array}$ & 0.921 & 1.000 & 1.000 \\
\hline
\end{tabular}

2014 yılında CCR modeli ile yapılan etkinlik ölçümü sonucunda 5 havayolu işletmesinin etkin çıtığ diğerlerinin ise etkin çıkmadığı görülmüştür. Girdi odaklı BBC modelinde ise 13 havayolu işletmesinin etkin çıktığı tespit edilmiştir. Aynı şekilde çıktı odaklı BBC modelinde de 13 havayolu işletmesi etkin çımıştır. 2013 yılında CCR modeline göre etkin çıkan havayolu işletmelerinden Air Canada ve Avusturya havayollarının 2014 yılında etkin çıkmadığı görülmüştür. Ürdün Kraliyet Havayolları işletmesinin ise 2013 yılında etkin değilken 2014 yllında ise etkin çıktığı görülmüştür. 2013 yılında girdi ve çıktı odaklı BCC modelinde etkin çıkmayan Aero Mexico, Japonya Havayolları ve Ürdün Kraliyet Havayolları işletmelerinin 2014 yılında etkin çıktığı görülmüştür. 
Tablo 5. Etkin Olmayan Havayolları ve Referans Değerleri Kümesi (2014)

\begin{tabular}{|c|c|c|c|c|c|}
\hline \multicolumn{2}{|l|}{ CCR Modeli } & \multicolumn{2}{|c|}{ Girdi Odaklı BCC Modeli } & \multicolumn{2}{|c|}{ Çıktı Odaklı BCC Modeli } \\
\hline $\begin{array}{l}\text { Etkin Olmayan } \\
\text { Havayolu } \\
\text { İşletmeleri }\end{array}$ & $\begin{array}{l}\text { Referans } \\
\text { Kümesi }\end{array}$ & $\begin{array}{l}\text { Etkin } \\
\text { Olmayan } \\
\text { Havayolu } \\
\text { İşletmeleri }\end{array}$ & $\begin{array}{l}\text { Referans } \\
\text { Kümesi }\end{array}$ & $\begin{array}{l}\text { Etkin } \\
\text { Olmayan } \\
\text { Havayolu } \\
\text { İşletmeleri }\end{array}$ & $\begin{array}{l}\text { Referans } \\
\text { Kümesi }\end{array}$ \\
\hline \multirow[t]{4}{*}{ Aeroflot } & Finnair (2.462) & \multirow[t]{4}{*}{ Aeroflot } & $\begin{array}{l}\text { Air Canada } \\
(0.280)\end{array}$ & \multirow[t]{4}{*}{ Aeroflot } & $\begin{array}{l}\text { Air Canada } \\
(0.439)\end{array}$ \\
\hline & $\begin{array}{l}\text { Aegean Havayolları } \\
(0.495)\end{array}$ & & $\begin{array}{l}\text { Tam Havayolları } \\
(0.057)\end{array}$ & & $\begin{array}{l}\text { Tam Havayolları } \\
(0.085)\end{array}$ \\
\hline & $\begin{array}{l}\text { Misır Havayolları } \\
(0.211)\end{array}$ & & $\begin{array}{l}\text { Türk Havayolları } \\
(0.095)\end{array}$ & & $\begin{array}{l}\text { Türk Havayolları } \\
(0.476)\end{array}$ \\
\hline & & & $\begin{array}{l}\text { Finnair } \\
(0.568)\end{array}$ & & \\
\hline \multirow[t]{2}{*}{ Aero Mexico } & Finnair (0.607) & & & & \\
\hline & $\begin{array}{l}\text { Aegean Havayolları } \\
(1.314)\end{array}$ & & & & \\
\hline \multirow[t]{2}{*}{ Air Canada } & Finnair (4.125) & & & & \\
\hline & $\begin{array}{l}\text { Aegean Havayolları } \\
(0.494)\end{array}$ & & & & \\
\hline \multirow[t]{2}{*}{$\begin{array}{l}\text { All Nippon } \\
\text { Havayolları }\end{array}$} & $\begin{array}{l}\text { Aegean Havayolları } \\
(4.525)\end{array}$ & & & & \\
\hline & Finnair (1.424) & & & & \\
\hline \multirow{2}{*}{$\begin{array}{l}\text { Avusturya } \\
\text { Havayolları }\end{array}$} & Finnair $(0.391)$ & & & & \\
\hline & $\begin{array}{l}\text { Aegean Havayolları } \\
(0.842)\end{array}$ & & & & \\
\hline \multirow[t]{3}{*}{ Avianca } & $\begin{array}{l}\text { Aegean Havayolları } \\
(2.488)\end{array}$ & & & & \\
\hline & Finnair $(0.273)$ & & & & \\
\hline & $\begin{array}{l}\text { Misir Havayolları } \\
(0.130)\end{array}$ & & & & \\
\hline \multirow[t]{3}{*}{$\begin{array}{l}\text { Japonya } \\
\text { Havayolları }\end{array}$} & $\begin{array}{l}\text { Aegean Havayolları } \\
(0.298)\end{array}$ & & & & \\
\hline & Finnair (2.429) & & & & \\
\hline & $\begin{array}{l}\text { Misır Havayolları } \\
(0.304)\end{array}$ & & & & \\
\hline \multirow[t]{4}{*}{$\begin{array}{l}\text { Kore } \\
\text { Havayolları }\end{array}$} & $\begin{array}{l}\text { Aegean Airlines } \\
(0.456)\end{array}$ & \multirow[t]{4}{*}{$\begin{array}{l}\text { Kore } \\
\text { Havayolları }\end{array}$} & $\begin{array}{l}\text { Air Canada } \\
(0.247)\end{array}$ & \multirow[t]{4}{*}{$\begin{array}{l}\text { Kore } \\
\text { Havayolları }\end{array}$} & $\begin{array}{l}\text { Air Canada } \\
(0.441)\end{array}$ \\
\hline & Finnair (2.561) & & $\begin{array}{l}\text { Tam Havayolları } \\
(0.099)\end{array}$ & & $\begin{array}{l}\text { Tam Havayolları } \\
(0.134)\end{array}$ \\
\hline & $\begin{array}{l}\text { Misır Havayolları } \\
(0.360)\end{array}$ & & $\begin{array}{l}\text { Türk Havayolları } \\
(0.088)\end{array}$ & & $\begin{array}{l}\text { Finnair } \\
(0.424)\end{array}$ \\
\hline & & & $\begin{array}{l}\text { Finnair } \\
(0.566)\end{array}$ & & \\
\hline \multirow[t]{3}{*}{$\begin{array}{l}\text { Güney Afrika } \\
\text { Havayolları }\end{array}$} & $\begin{array}{l}\text { Ürdün Kraliyet } \\
\text { Havayolları }(0.351)\end{array}$ & \multirow{3}{*}{$\begin{array}{l}\text { Güney } \\
\text { Afrika } \\
\text { Havayolları }\end{array}$} & $\begin{array}{l}\text { Finnair } \\
(0.625)\end{array}$ & \multirow[t]{3}{*}{$\begin{array}{l}\text { Güney Afrika } \\
\text { Havayolları }\end{array}$} & $\begin{array}{l}\text { Finnair } \\
(0.969)\end{array}$ \\
\hline & Finnair $(0.874)$ & & $\begin{array}{l}\text { Misir Havayolları } \\
(0.119)\end{array}$ & & Tam Havayolları \\
\hline & $\begin{array}{l}\text { Misır Havayolları } \\
(0.166)\end{array}$ & & $\begin{array}{l}\text { Ürdün Kraliyet } \\
\text { Havayolları }(0.256)\end{array}$ & & $(0.031)$ \\
\hline \multirow{2}{*}{$\begin{array}{l}\text { Tam } \\
\text { Havayolları }\end{array}$} & Finnair (3.854) & & & & \\
\hline & $\begin{array}{l}\text { Misir Havayolları } \\
(0.636)\end{array}$ & & & & \\
\hline $\begin{array}{l}\text { Türk Hava } \\
\text { Yolları }\end{array}$ & $\begin{array}{l}\text { Finnair (2.732) } \\
\text { Aegean Havayolları } \\
(3.281)\end{array}$ & & & & \\
\hline
\end{tabular}


Veri zarflama analizi yöntemi ile etkin çımayan karar verme birimlerinin etkin duruma geçebilmesi için referans alması gereken karar verme birimleri belirlenerek referans kümesi oluşturulmaktadır. Etkin çıkmayan havayolu işletmelerinin etkin duruma geçebilmesi için örnek almaları gereken havayolu işletmeleri ile bu havayolu işletmelerinin 2014 yllına ait referans değerleri Tablo 5’te verilmiştir.

Tablo 5'e göre Aeroflot havayolu işletmesinin CCR modeline göre etkin duruma geçebilmesi için 2.462 oranında Finnair, 0.465 oranında Aegean Havayolları ve 0.211 oranında Mısır Havayolları işletmesini ör- nek alması gerekmektedir. Bu açıdan Aeroflot havayolu işletmesinin CCR modeline göre etkin duruma geçebilmesi için girdi değişkenlerini 2.462 oranında azaltması, çıktı değişkenlerini de 2.462 oranında arttırarak Finnair'e benzetmesi gerekmektedir. Veri zarflama analizi tekniğinde etkin olmayan havayolu işletmelerinin etkin duruma geçebilmeleri için girdi ve çıktı değişkenlerini arttırmaları veya azaltmaları gerekmektedir. CCR modeline göre etkinlik sınırının altında kalan havayolu işletmelerinin etkin duruma geçebilmeleri için mevcut girdi-çıktı kümesini ne kadar değiştireceği Tablo 6'da verilmiştir.

Tablo 6. CCR Modeline göre Etkin Olmayan Havayolu İşletmelerinin Mevcut Değerleri ile Etkinliğe Ulaşabilmeleri Için Gerekli Olan Hedef Girdi Değişkenleri(2013)

\begin{tabular}{|c|c|c|c|c|c|c|c|c|}
\hline $\begin{array}{c}\text { Etkin Olmayan } \\
\text { Havayolu } \\
\text { Işletmeleri }\end{array}$ & Mevcut & $\begin{array}{c}\text { Hedef } \\
\text { (CCR) }\end{array}$ & Mevcut & $\begin{array}{c}\text { Hedef } \\
\text { (CCR) }\end{array}$ & Mevcut & $\begin{array}{c}\text { Hedef } \\
\text { (CCR) }\end{array}$ & Mevcut & $\begin{array}{c}\text { Hedef } \\
\text { (CCR) }\end{array}$ \\
\hline Aeroflot & 26998 & 26998 & 76500 & 76500 & 3306000 & 3089522 & 17890 & 9511 \\
\hline Aero Mexico & 13688 & 13688 & 32496 & 32496 & 1380000 & 1215881 & 13652 & 4314 \\
\hline $\begin{array}{c}\text { All Nippon } \\
\text { Havayolları }\end{array}$ & 48433 & 41395 & 102497 & 102497 & 2991000 & 2991000 & 14196 & 14196 \\
\hline $\begin{array}{c}\text { Avianca } \\
\text { Japon }\end{array}$ & 18529 & 18115 & 38762 & 38762 & 1326000 & 1326000 & 19153 & 6395 \\
\hline $\begin{array}{c}\text { Havayolları } \\
\text { Kore Havayolları }\end{array}$ & 30914 & 30914 & 89110 & 89110 & 3946000 & 3429740 & 19470 & 11003 \\
\hline $\begin{array}{c}\text { Ürdün Kraliyet } \\
\text { Havayolları }\end{array}$ & 5081 & 5081 & 12000 & 12000 & 833000 & 560347 & 4643 & 2279 \\
\hline $\begin{array}{c}\text { Güney Afrika } \\
\text { Havayolları }\end{array}$ & 11314 & 11314 & 33441 & 33441 & 1761000 & 1196187 & 11462 & 4088 \\
\hline Tam Havayolları & 58943 & 47621 & 131691 & 131691 & 4414000 & 4414000 & 52997 & 24998 \\
\hline $\begin{array}{c}\text { Türk Hava } \\
\text { Havayolları }\end{array}$ & 42236 & 42236 & 116433 & 116433 & 4947000 & 3470006 & 18882 & 14554 \\
\hline
\end{tabular}


Tablo 7. CCR Modeline göre Etkin Olmayan Havayolu Işletmelerinin Mevcut Değerleri ile Etkinliğe Ulaşabilmeleri Için Gerekli Olan Hedef Çıktı Değişkenleri( 2013)

\begin{tabular}{|c|c|c|c|c|c|c|}
\hline \multirow{2}{*}{$\begin{array}{c}\text { Etkin Olmayan } \\
\text { Havayolu İşletmeleri }\end{array}$} & \multicolumn{2}{|c|}{ Taşınan Yolcu Sayısı } & \multicolumn{2}{|c|}{ RPK } & \multicolumn{2}{|c|}{ Doluluk Oranı } \\
\hline & Mevcut & $\begin{array}{l}\text { Hedef } \\
(\mathrm{CCR})\end{array}$ & Mevcut & Hedef (CCR) & Mevcut & $\begin{array}{l}\text { Hedef } \\
(\mathrm{CCR})\end{array}$ \\
\hline Aeroflot & 20900000 & 25288829 & 60200 & 69056 & 79 & 85.5 \\
\hline Aero Mexico & 15500000 & 17580626 & 24474 & 27759 & 77 & 84 \\
\hline $\begin{array}{ll}\text { All } & \text { Nippon } \\
\text { Havayolları } & \end{array}$ & 45700000 & 55254539 & 68474 & 82789 & 67 & 77 \\
\hline Avianca & 24600000 & 25390107 & 31200 & 32202 & 81 & 86.5 \\
\hline Japon Havayolları & 24100000 & 29433982 & 59136 & 72224 & 71 & 78.2 \\
\hline Kore Havayolları & 23600000 & 29159083 & 68361 & 79440 & 77 & 82.1 \\
\hline $\begin{array}{ll}\text { Ürdün } & \text { Kraliyet } \\
\text { Havayolları } & \end{array}$ & 3308000 & 5170223 & 8400 & 10901 & 70 & 82.5 \\
\hline $\begin{array}{l}\text { Güney Afrika } \\
\text { Havayolları }\end{array}$ & 7100000 & 10782338 & 24880 & 29274 & 74 & 83.4 \\
\hline Tam Havayolları & 37400000 & 41335488 & 106466 & 117669 & 81 & 87.5 \\
\hline $\begin{array}{l}\text { Türk Hava } \\
\text { Havayolları }\end{array}$ & 48300000 & 50305186 & 91997 & 95816 & 79 & 85 \\
\hline
\end{tabular}

Tablo 8. Girdi ve çıktı odaklı BCC Modeline göre Etkin Olmayan Havayolu Iş̧letmelerinin Mevcut Değerleri ile Etkinliğe Ulaşabilmeleri İ̧in Gerekli Olan Hedef Girdi Değişkenleri( 2013)

\begin{tabular}{|c|c|c|c|c|c|c|c|c|}
\hline Etkin & \multicolumn{2}{|c|}{ Çalışan sayısı } & \multicolumn{2}{|c|}{ ASK } & \multicolumn{2}{|c|}{$\begin{array}{l}\text { Yakıt } \\
\text { (Milyon\$) }\end{array}$} & \multicolumn{2}{|c|}{$\begin{array}{c}\text { Koltuk } \\
\text { Kapasitesi }\end{array}$} \\
\hline $\begin{array}{c}\text { Olmayan } \\
\text { Havayolu } \\
\text { İşletmeleri }\end{array}$ & Mevcut & $\begin{array}{l}\text { Hedef } \\
\text { (BCC) }\end{array}$ & Mevcut & $\begin{array}{l}\text { Hedef } \\
\text { (BCC) }\end{array}$ & Mevcut & $\begin{array}{l}\text { Hedef } \\
\text { (BCC) }\end{array}$ & Mevcut & $\begin{array}{l}\text { Hedef } \\
(\mathrm{BCC})\end{array}$ \\
\hline Aeroflot & 26998 & 26464 & 76500 & 76500 & 3306000 & 1806766 & 17890 & 17890 \\
\hline Aero Mexico & 13688 & 13688 & 32496 & 32496 & 1380000 & 985932 & 13652 & 11633 \\
\hline $\begin{array}{c}\text { Japon } \\
\text { Havayolları }\end{array}$ & 39421 & 29949 & 83319 & 83319 & 2528000 & 2036508 & 31472 & 21853 \\
\hline $\begin{array}{c}\text { Kore } \\
\text { Havayolları }\end{array}$ & 30914 & 30095 & 89110 & 89110 & 3946000 & 2035655 & 19470 & 19470 \\
\hline $\begin{array}{c}\text { Ürdün } \\
\text { Kraliyet } \\
\text { Havayolları }\end{array}$ & 5081 & 5081 & 12000 & 11694 & 833000 & 343793 & 4643 & 1742 \\
\hline $\begin{array}{c}\text { Güney Afrika } \\
\text { Havayolları }\end{array}$ & 11314 & 11314 & 33441 & 33441 & 1761000 & 804536 & 11462 & 5836 \\
\hline
\end{tabular}


Tablo 9. Girdi ve çıktı odaklı BCC Modeline göre Etkin Olmayan Havayolu İşletmelerinin Mevcut Değerleri ile Etkinliğe Ulaşabilmeleri İ̧̧in Gerekli Olan Hedef Çıktı Değişkenleri(2013)

\begin{tabular}{|c|c|c|c|c|c|c|}
\hline \multirow{2}{*}{$\begin{array}{c}\text { Etkin Olmayan } \\
\text { Havayolu } \\
\text { Issletmeleri }\end{array}$} & Mevcut & $\begin{array}{c}\text { Hedef } \\
\text { (BCC) }\end{array}$ & Mevcut & Hedef (BCC) & Mevcut & Hedef \\
\hline Aeroflot & 20900000 & 26014158 & 60200 & 62827 & 79 & 81.6 \\
\hline Aero Mexico & 15500000 & 17402239 & 24474 & 26033 & 77 & 80.4 \\
\hline Japon Havayolları & 24100000 & 30255787 & 59136 & 68556 & 71 & 82.1 \\
\hline Kore Havayolları & 23600000 & 28390681 & 68361 & 73402 & 77 & 81.9 \\
\hline Ürdün Kraliyet & 3308000 & 7255121 & 8400 & 9220 & 70 & 79.5 \\
\hline Havayolları & & & & & & \\
\hline Güney Afrika & 7100000 & 12326719 & 24880 & 26913 & 74 & 80 \\
\hline Havayolları & & & & & & \\
\hline
\end{tabular}

Tablo 10. CCR Modeline göre Etkin Olmayan Havayolu İşletmelerinin Mevcut Değerleri ile Etkinliğe Ulaşabilmeleri Için Gerekli Olan Hedef Girdi Değişkenleri( 2014)

\begin{tabular}{|c|c|c|c|c|c|c|c|c|}
\hline \multirow{2}{*}{$\begin{array}{c}\text { Etkin Olmayan } \\
\text { Havayolu } \\
\text { Işletmeleri }\end{array}$} & \multicolumn{2}{|c|}{ Çalışan sayısı } & \multicolumn{2}{|c|}{ ASK } & \multicolumn{2}{|c|}{$\begin{array}{l}\text { Yakit } \\
\text { (Milyon\$) }\end{array}$} & \multicolumn{2}{|c|}{$\begin{array}{c}\text { Koltuk } \\
\text { Kapasitesi }\end{array}$} \\
\hline & Mevcut & $\begin{array}{l}\text { Hedef } \\
\text { (CCR) }\end{array}$ & Mevcut & $\begin{array}{l}\text { Hedef } \\
(\mathrm{CCR})\end{array}$ & Mevcut & $\begin{array}{l}\text { Hedef } \\
(\mathrm{CCR})\end{array}$ & Mevcut & $\begin{array}{l}\text { Hedef } \\
(\mathrm{CCR})\end{array}$ \\
\hline Aeroflot & 28788 & 28788 & 85800 & 85800 & 3735000 & 2324029 & 18981 & 10905 \\
\hline Aero Mexico & 14799 & 14799 & 36217 & 34779 & 1485000 & 837240 & 12910 & 4879 \\
\hline Air Canada & 44450 & 41498 & 136842 & 133441 & 2871000 & 2871000 & 24400 & 16384 \\
\hline $\begin{array}{l}\text { All Nippon } \\
\text { Havayolları }\end{array}$ & 50764 & 44809 & 109700 & 99173 & 3222000 & 2445688 & 14314 & 14314 \\
\hline $\begin{array}{l}\text { Avusturya } \\
\text { Havayolları }\end{array}$ & 10493 & 9503 & 23343 & 22358 & 538000 & 538000 & 6067 & 3135 \\
\hline Avianca & 22092 & 21547 & 41052 & 41052 & 1346000 & 1346000 & 20545 & 6413 \\
\hline $\begin{array}{c}\text { Japonya } \\
\text { Havayolları }\end{array}$ & 40138 & 28252 & 84003 & 84003 & 2476000 & 2476000 & 31534 & 10709 \\
\hline Kore Havayolları & 31271 & 31271 & 90979 & 90979 & 3656000 & 2761128 & 20543 & 11708 \\
\hline $\begin{array}{l}\text { Güney Afrika } \\
\text { Havayolları }\end{array}$ & 11590 & 1159 & 33999 & 33999 & 1945000 & 1268511 & 11491 & 5391 \\
\hline Tam Havayolları & 57653 & 43420 & 130201 & 130201 & 4167000 & 4167000 & 53072 & 16579 \\
\hline $\begin{array}{c}\text { Türk Hava } \\
\text { Yolları }\end{array}$ & 48163 & 48163 & 135330 & 124406 & 5858000 & 2888206 & 19902 & 16724 \\
\hline
\end{tabular}


Tablo 11. CCR Modeline göre Etkin Olmayan Havayolu Iş̧letmelerinin Mevcut Değerleri ile Etkinliğe Ulaşabilmeleri Için Gerekli Olan Hedef Çıktı Değişkenleri( 2014)

\begin{tabular}{|c|c|c|c|c|c|c|}
\hline \multirow[b]{2}{*}{$\begin{array}{c}\text { Etkin Olmayan } \\
\text { Havayolu İşletmeleri }\end{array}$} & \multicolumn{2}{|c|}{ Taşınan Yolcu Sayısı } & \multicolumn{2}{|c|}{ RPK } & \multicolumn{2}{|c|}{ Doluluk Oranı } \\
\hline & Mevcut & $\begin{array}{l}\text { Hedef } \\
(\mathrm{CCR})\end{array}$ & Mevcut & Hedef (CCR) & Mevcut & $\begin{array}{l}\text { Hedef } \\
\text { (CCR) }\end{array}$ \\
\hline Aeroflot & 23600000 & 30497719 & 67100 & 86711 & 78 & 88 \\
\hline Aero Mexico & 17200000 & 19102978 & 28245 & 31369 & 80 & 85 \\
\hline Air Canada & 38500000 & 44588906 & 114113 & 132160 & 83 & 90 \\
\hline $\begin{array}{l}\text { All Nippon } \\
\text { Havayolları }\end{array}$ & 50400000 & 59374265 & 74221 & 87436 & 68 & 77 \\
\hline $\begin{array}{l}\text { Avusturya } \\
\text { Havayolları }\end{array}$ & 11200000 & 12261374 & 18428 & 20174 & 79 & 86 \\
\hline Avianca & 26200000 & 28895984 & 32602 & 35956 & 79 & 87 \\
\hline Japonya Havayolları & 28200000 & 29003449 & 84003 & 86396 & 72 & 80 \\
\hline Kore Havayolları & 23500000 & 32356280 & 67948 & 93555 & 75 & 80 \\
\hline $\begin{array}{c}\text { Güney Afrika } \\
\text { Havayolları }\end{array}$ & 7000000 & 10998518 & 25606 & 35734 & 75 & 81 \\
\hline Tam Havayolları & 37900000 & 42593048 & 130201 & 136828 & 83 & 89 \\
\hline Türk Hava Yolları & 54700000 & 59365923 & 106787 & 115895 & 79 & 86 \\
\hline
\end{tabular}

Tablo 12. Girdi ve Çıktı Odaklı BCC Modeline göre Etkin Olmayan Havayolu Iş̧letmelerinin Mevcut Değerleri ile Etkinliğe Ulaşabilmeleri İ̧in Gerekli Olan Hedef Girdi Değişkenleri( 2014)

\begin{tabular}{|c|c|c|c|c|c|c|c|c|}
\hline \multirow{2}{*}{$\begin{array}{c}\text { Etkin Olmayan } \\
\text { Havayolu } \\
\text { Issletmeleri }\end{array}$} & \multicolumn{2}{|c|}{ Çalışan sayısı } & \multicolumn{2}{|c|}{ ASK } & \multicolumn{2}{|c|}{$\begin{array}{l}\text { Yakıt } \\
\text { (Milyon\$) }\end{array}$} & \multicolumn{2}{|c|}{$\begin{array}{c}\text { Koltuk } \\
\text { Kapasitesi }\end{array}$} \\
\hline & Mevcut & $\begin{array}{l}\text { Hedef } \\
(\mathrm{BCC})\end{array}$ & Mevcut & $\begin{array}{l}\text { Hedef } \\
(\mathrm{BCC})\end{array}$ & Mevcut & $\begin{array}{l}\text { Hedef } \\
(\mathrm{BCC})\end{array}$ & Mevcut & $\begin{array}{l}\text { Hedef } \\
(\mathrm{BCC})\end{array}$ \\
\hline Aeroflot & 28788 & 28788 & 85800 & 85800 & 3735000 & 1925796 & 18981 & 16989 \\
\hline $\begin{array}{c}\text { Kore } \\
\text { Havayolları }\end{array}$ & 31271 & 31271 & 90979 & 90979 & 3656000 & 2104923 & 20543 & 19479 \\
\hline $\begin{array}{c}\text { Güney Afrika } \\
\text { Havayolları }\end{array}$ & 11590 & 10738 & 33999 & 33999 & 1945000 & 765948 & 11491 & 5279 \\
\hline
\end{tabular}

Tablo 13. Girdi ve Çıktı Odaklı BCC Modeline göre Etkin Olmayan Havayolu Işsletmelerinin Mevcut Değerleri ile Etkinliğe Ulaşabilmeleri Için Gerekli Olan Hedef Çıktı Değişkenleri( 2014)

\begin{tabular}{|c|c|c|c|c|c|c|}
\hline \multirow[b]{2}{*}{$\begin{array}{c}\text { Etkin Olmayan } \\
\text { Havayolu İşletmeleri }\end{array}$} & \multicolumn{2}{|c|}{ Taşınan Yolcu Sayısı } & \multicolumn{2}{|c|}{ RPK } & \multicolumn{2}{|c|}{ Doluluk Oranı } \\
\hline & Mevcut & $\begin{array}{l}\text { Hedef } \\
(\mathrm{BCC})\end{array}$ & Mevcut & Hedef (BCC) & Mevcut & $\begin{array}{l}\text { Hedef } \\
(\mathrm{BCC})\end{array}$ \\
\hline Aeroflot & 2360000 & 24680540 & 67100 & 75829 & 78 & 81.5 \\
\hline Kore Havayolları & 23500000 & 26153000 & 67948 & 80949 & 75 & 81 \\
\hline $\begin{array}{c}\text { Güney Afrika } \\
\text { Havayolları }\end{array}$ & 7000000 & 10486227 & 25606 & 33999 & 75 & 80.1 \\
\hline
\end{tabular}


Tablo 14. Etkin Havayolu Işsletmeleri ve Referans Sayıları

\begin{tabular}{|c|c|c|c|c|c|c|}
\hline \multirow{2}{*}{$\begin{array}{l}\text { Etkin } \\
\text { İşletmeleri }\end{array}$} & \multicolumn{2}{|c|}{ CCR Modeli } & \multicolumn{2}{|c|}{ Modeli } & \multicolumn{2}{|c|}{ Çıktı Odakı BCC Modeli } \\
\hline & 2013 & 2014 & 2013 & 2014 & 2013 & 2014 \\
\hline Aegean Havayolları & 5 & 9 & 2 & - & 2 & - \\
\hline Air Canada & 4 & - & 3 & 2 & 4 & 2 \\
\hline Avianca & & - & 2 & - & 4 & - \\
\hline $\begin{array}{l}\text { Hırvatistan } \\
\text { Havayolları }\end{array}$ & 1 & - & 2 & - & 1 & - \\
\hline Misır Havayolları & 9 & 6 & 5 & 1 & - & - \\
\hline Finnair & 6 & 11 & 3 & 3 & 4 & 3 \\
\hline $\begin{array}{ll}\text { Urdün } & \text { Kraliyet } \\
\text { Havayolları } & \end{array}$ & - & 1 & - & 1 & - & - \\
\hline Tam Havayolları & - & - & - & 2 & - & 3 \\
\hline Türk Hava Yolları & & & 1 & 2 & - & - \\
\hline
\end{tabular}

Analiz sonucunda etkin çıkan havayolu işletmelerinin etkin çıkmayan havayolu işletmeleri tarafından kaç defa referans gösterildiği Tablo 14'te verilmiştir.

\section{Sonuç}

Bu çalışmada bulundukları ülkelerin bayrak taşıyıcıs1 olan 16 geleneksel havayolu işletmesinin 2013 ve 2014 yılarına ait finansal ve operasyonel etkinlik ölçümü yapılmıştır. 2013 ve 2014 yıllarının seçilmesinin nedeni 2012 yılındaki yakıt fiyatlarının en yüksek seviye ulaşması ile birlikte takip eden yıllarda ilgili havayolu işletmelerinin bu durumdan etkilenip etkilenmediğinin tespit edilmesidir. Veri yetersizliğinden dolayı araştırmaya sadece 16 havayolu işletmesi dâhil edilebilmiştir.

Araştırmada veri zarflama analizi tekniğinin çıtı odaklı CCR modeli ile girdi ve çıktı odaklı BCC modelleri kullanılmıştır. Analizin güvenilir sonuçlar vermesi için girdi ve çıtı değişkenlerinin kendi içerisinde anlamlı olması gerekmektedir. Bu açıdan bu çalışmada havayolu işletmelerinin verimliliklerini önemli ölçüde yansıtan çalışan sayısı, ASK, yakıt gideri ve koltuk kapasitesi gibi girdi değişkenleri kullanılmış çıktı olarak ise RPK, doluluk oranı ile toplam taşınan yolcu sayısı kullanılmıştır. Girdi değişkenleri içerisinde yer alan yakıt gideri havayolu işletmelerinin verimlilik ve etkinliklerini doğrudan etkilemektedir.

Veri zarflama analizinin CCR modeli ile yapilan etkinlik ölçümünde 2013 yılında 6 havayolu işletmesi etkin çıkarken 2014 yılında etkin havayolu işletmesi 5’e düşmüștür. Air Canada ve Avusturya Havayollar1 işletmelerinin 2013 yılında etkin oldukları 2014 yılında ise etkinlik sınırının altında kaldıkları görülmüştür. Air Canada Havayolları işletmesinin 2014 yllında etkin çıkmamasının nedeni çalışan sayısının azaltılması ile birlikte yakıt gideri, koltuk kapasitesi ile ASK’nın artması ve çıktı değişkeni olan doluluk oranın değişmemesidir. Avusturya Havayollarının 2014 yılında etkin çıkmamasının nedeni ise toplam taşınan yolcu sayısının azalmasına rağmen ASK ve koltuk kapasitesinin arttırılmasıdır. 2014 yılında etkin çıan Ürdün Kraliyet Havayolları işletmesinin ise 2013 yılında etkin olmadığı görülmüştür. İlgili havayolu işletmesinin etkin çıkmamasının nedeni çalışan sayısının, yakıt tüketimin, ASK ve koltuk kapasitesinin 2014 yilına göre daha fazla olmasıdır.

Girdi ve çıktı odaklı BCC modeli ile yapılan etkinlik ölçümünde 2013 yllında 10 havayolu işletmesi etkin çıarken 2014 yllında etkin havayolu işletmesi 13'e yükselmiştir. Aeromexico, Japon Havayolları ve Ürdün Kraliyet Havayolları işletmelerinin 2013 yılında etkin çıkmadıkları 2014 yılında ise etkin duruma geç- 
tikleri görülmüştür. AeroMexico havayolu işletmesinin 2013 yılında etkin çıkmamasının nedeni çalışan sayısının bir sonraki yıla göre daha fazla olmasıdır. ASK ve koltuk kapasitesinin ise bir sonraki yıla göre daha düşük olmasıdır. Aynı şekilde RPK ile toplam taşınan yolcu sayısının bir sonraki yıla göre daha az olmasıdır. Japon Havayolları işletmesinin ise 2013 yılındaki tüm girdi ve çıktı değişkenlerinin 2014 yılının oldukça gerisinde kaldığından dolayı 2013 yılında etkinlik sınırının altında kalmıştır. Ürdün Kraliyet Havayolları işletmesinin ise 2013 yılında CCR modelinde olduğu gibi girdi ve çıktı odaklı BBC modelinde de etkin çımadığı görülmüştür.

Analiz sonucunda etkin çıan havayolu işletmeleri içerisinde etkin olmayan havayolu işletmeleri tarafından en fazla referans gösterilen havayolu işletmesinin Finnair olduğu görülmüştür. Finnair'den sonra sırası ile Misır Havayolları ile Aegean Havayolları en fazla referans gösterilen havayolu işletmeleridir. 2013 y1lındaki etkinlik ölçümüne göre etkin olmayan havayolu işletmeleri içerisinde en düşük performansı Ürdün Kraliyet Havayolları ile Japon Havayolları göstermiştir. 2014 yılında ise Güney Afrika Havayolları ile Kore Havayolları en düşük performansı sergilemiştir.

Araştırma sonucunda etkin olmayan havayolu işletmelerinin etkin duruma geçebilmeleri için yakıt maliyetlerini azaltmaları ve koltuk kapasitesini düşürmeleri gerektiği bununla birlikte doluluk oranın arttırılması gerektiği tespit edilmiştir. Koltuk kapasitesinin azaltılması, ilgili havayolu işletmelerinin küçük uçaklardan oluşan bir filoya sahip olmasını gerektirmektedir. Bunun yanında ilgili havayolu işletmeleri bulundukları stratejik ittifaklarda kod paylaşımı uygulamasına giderek etkinliklerini arttırabilirler.

Havayolu işletmelerinin etkinlik ölçümünün yapıld1ğ çalışmalara bakıldığında birçok çalışmada sadece etkinlik ölçümünün yapıldığı görülmüş referans kümesinin belirlenmesi, etkin olan havayolu işletmelerinin etkin olmayan havayolu işletmeleri tarafından kaç defa referans gösterildiği gibi veri zarflama analizinin önemli kısımları belirtilmemiştir. Bu açıdan bu çalışmanın bu yönü ile benzer çalışmalardan farklı olduğu söylenebilmektedir. Geleneksel havayolu işletmelerinin etkinlik ölçümün yapıldığı bu çalışmanın bu alandaki literatüre katkısı olduğu düşünülmektedir. Bununla birlikte havayolu yöneticilerine yardımcı olabilecek bilgiler içermektedir. Havayolu işletmele- rindeki yöneticiler, etkinlik ölçümü sonucunda elde edilen verileri analiz ederek operasyonel ve finansal performansı arttırmak için yeni stratejiler belirleyip bu stratejileri izleyebilirler.

Girdi ve çıktı değişkenlerinin seçimi etkinlik ölçümünün sonucunu değiştirmektedir. Bununla birlikte havacilık alanındaki düzenlemeler ve vergilendirme usulleri de verimlik ve etkinlik ölçümünü etkilemektedir.

Araştırmaya dahil edilen havayolu işletmelerinin tümü geleneksel havayolu işletmesidir. Bu açıdan ilerleyen çalışmalarda geleneksel havayolu işletmeleri ile düşük maliyetli havayolu işletmelerinin karşılaşt1rılabildiği çalışmalar yapılabilir.

\section{Kaynakça}

Alam, I. S., Sickles, R. C. (1998). The Relationship Between Stock Market Returns and Technical Efficiency Innovations: Evidence from the US Airline Industry. Journal of Productivity Analysis, 35-51. 10.1023/A:1018368313411

Arjomandi, A., Seufert, J. H. (2014). An evaluation of the world's major airlines' technical and environmental performance.Economic Modelling, 133-144. http://ro.uow.edu.au/cgi/viewcontent.cgi?article $=1$ 384\&context=buspapers

Banker, R., Cooper, W. W., Seiford, L. M., Thrall, R. M., \& Zhu, J. (2004). Returns to scale in different DEA models. European Journal of Operational Research, 345-362. 10.1016/S0377-2217(03)00174-7

Barbot, C., Costa, Á., \& Sochirca, E. (2008). Airlines performance in the new market context: A comparative productivity and efficiency analysis. Journal of Air Transport Management, 270-274. 10.1016/j. jairtraman.2008.05.003

Barros, C. P. (2009). An evaluation of European airlines' operational performance. International Journal of Production Economics, 525-533. 10.1016/j. ijpe.2009.04.016 
Barros, C. P., Liang, Q. B., \& Peypoch, N. (2013). The technical efficiency of US Airlines. Transportation Research Part A: Policy and Practice, 139-148. 10.1016/j.tra.2013.01.019

Bhadra, D. (2009). Race to the bottom or swimming upstream: Performance analysis of US airlines. Journal of Air Transport Management, 227-235. 10.1016/j.jairtraman.2008.09.014

Cao, Q., Lv, J., \& jun, Z. (2015). Productivity efficiency analysis of the airlines in China after deregulation. Journal of Air Transport Management, 135-140. /10.1016/j.jairtraman.2014.09.009

Chen, Y., \& Ali, A. I. (2002). Continuous optimization output-input ratio analysis and dea frontier. European Journal of Operational Research, 476-479. S 0 $377-2217$ ( 01$) 00318-6$

Chiou, Y. C., \& Chen, Y.-H. (2006). Route-based performance evaluation of Taiwanese domestic airlines using data envelopment analysis. Transportation Research Part E: Logistics and Transportation Review, 116-127. 10.1016/j.tre.2005.09.005

Chow, C. K. (2010). Measuring the productivity changes of Chinese airlines: The impact of the entries of non-state-owned carriers. Journal of Air Transport Management, 320-324. 10.1016/j.jairtraman.2010.04.001

Coelli, T., Rao, P., O’Donnell, C., \& Battese, G. (2005). An introduction to efficiency and productivity analysis. Austrailia: Springer.

Cooper, W. W., L1, S., Seiford, L. M., Tone, K., Thrall, R. M., \& Zhu, J. (2001). Sensitivity and Stability Analysis in DEA: Some Recent Developments. Journal of Productivity Analysis, 217-246. 10.1023/A:1011128409257

Cooper, W. W., Seiford, L. M., \& Tone, K. (2006). İntroduction to data envelopment analysis and it uses. Newyork: Springer.
Dyson, R. G., Allen, R., Camanho, A. S., Podinovski, V. V., Sarrico, C. S., \& Shale, E. A. (2001). Pitfalls and protocols in DEA. European Journal of Operational Research, 245-259. 10.1016/S0377-2217(00)00149-1

Golany, B., \& Roll, Y. (1989). An Application Procedure For DEA. Omega, 17(3), 237-250. 10.1016/03050483(89)90029-7

Good, H. D., Röller, L.-H., \& Sickles, R. C. (1995). Airline efficiency differences between Europe and the US: Implications for the pace of EC integration and domestic regulation . European Journal of Operational Research, 508-518. 10.1016/0377-2217(94)00134-X

Gramani, M. C. (2012). Efficiency decomposition approach: A cross-country airline analysis. Expert Systems with Applications, 5815-5819. 0.1016/j. eswa.2011.11.086

Greer, M. (2008). Nothing focuses the mind on productivity quite like the fear of liquidation: Changes in airline productivity in the United States, 20002004. Transportation Research Part A: Policy and Practice, 414-426. 10.1016/j.tra.2007.11.001

Greer, M. (2009). Is it the labor unions' fault? Dissecting the causes of the impaired technical efficiencies of the legacy carriers in the United States. Transportation Research Part A: Policy and Practice, 779-789. 10.1016/j.tra.2009.07.007

Güran, M. C., \& Cingi, S. (2002). Devletin ekonomik müdahalelerinin etkinliği. Akdeniz İ.̇.B.F. Dergisi, 56-69. http://www.acarindex.com/dosyalar/makale/acarindex-1423868928.pdf

Hong, S., \& Zhang, A. (2010). An efficiency study of airlines and air cargo/passenger divisions: a DEA approach. World Review of Intermodal Transportation Research, 137-149. 10.1504/WRITR.2010.031584

İşbilen Yücel, L. (2010). Portföy Etkinliğinin Veri Zarflama Analizi İle Ölçülmesi ve Portföy Etkinleștirilmesine Yönelik Bir Uygulama. İstanbul: İstanbul Üniversitesi. Yayınlanmamış Doktora Tezi 
Karsak, E., \& İşcan, F. (2000). Çimento sektöründe göreli faaliyet performanslarının ağırlık kısıtlamaları ve çapraz etkinlik kullanılarak veri zarflama analizi ile değerlendirilmesi. Endüstri Mühendisliği Dergisi, 2-10. http://arsiv.mmo.org.tr/pdf/11754.pdf

Kazançoğlu, Y. (2008). Lojistik yönetim sürecinde tedarikçi seçimi ve performans değerlendirilmesinin yöneylem araştırması teknikleri ile gerçekleştirilmesi. İzmir: Ege Üniversitesi. Yayınlanmamış Doktora Tezi

Kutlar, A., \& Kartal, M. (2004). Cumhuriyet üniversitesinin verimlilik analizi: fakülteler düzeyinde veri zarflama yöntemiyle bir uygulama. Kocaeli Üniversitesi Sosyal Bilimler Enstitüsü Dergisi, 8(2), 49-79. http://www.acarindex.com/dosyalar/makale/acarindex-1423907864.pdf

Lang, P., Yolalan, R., \& Kettani, O. (1995). Controlled envelopment by face extension. Journal of the Operational Research Societ, 473-491. https://www. jstor.org/stable/pdf/2584595.pdf

Lee, B. L., \& Worthington, A. C. (2014). Technical efficiency of mainstream airlines and low-cost carriers: New evidence using bootstrap data envelopment analysis truncated regression. Journal of Air Transport Management, 15-20. 10.1016/j.jairtraman.2013.12.013

Lorcu, F. (2008). Veri zarflama analizi (dea) ile türkiye ve avrupa birliği ülkelerinin sağlik alanındaki etkinliklerinin değerlendirilmesi. İstanbul: İstanbul Üniveristesi. Yayınlanmamış Doktora Tezi

Lovell, C., \& Pastor, J. (1997). Target setting: an application to a bank branch network. European Journal of Operational Research, 98(2), 290-299. 10.1016/ S0377-2217(96)00348-7

Lu, W.-M., Wang, W.-K., Hung, S.-W., \& Lu, E.-T. (2012). The effects of corporate governance on airline performance: Production and marketing efficiency perspectives. Transportation Research Part E: Logistics and Transportation Review, 529-544. 10.1016/j.tre.2011.09.003
Mallikarjun, S. (2015). Efficiency of US airlines: A strategic operating model. Journal of Air Transport Management, 45-56. 10.1016/j.jairtraman.2014.12.004

Matthews, K., \& Ismail, M. (2006). Efficiency and productivity growth of domestic and foreign commercial banks in malaysia. Cardiff: Cardiff Business School. 7-8 http://business.cardiff.ac.uk/sites/default/files/ e2006_2.pdf

Merkert, R., \& Hensher, D. A. (2011). The impact of strategic management and fleet planning on airline efficiency - A random effects Tobit model based on DEA efficiency scores. Transportation Research Part A: Policy and Practice, 686-695. 10.1016/j. tra.2011.04.015

Saranga, H., \& Nagpal, R. (2016). Drivers of operational efficiency and its impact on market performance in the Indian Airline industry. Journal of Air Transport Management, 53, 165-176. 10.1016/j. jairtraman.2016.03.001

Schefczyk, M. (1993). Operational Performance Of Airlines: An Extension Of Traditional Measurment Paradigms. Strategic Management Journal, 14, 301-317. file://C:/Users/user/Downloads/operation\%20performace\%20of\%20airlines.pdf

Scheraga, C. A. (2004). Operational efficiency versus financial mobility in the global airline industry: a data envelopment and Tobit analysis. Transportation Research Part A: Policy and Practice, 383-404. 10.1016/j.tra.2003.12.003

See, K. F., \& Rashid, A. A. (2016). Total factor productivity analysis of Malaysia Airlines: Lessons from the past and directions for the future. Research in Transportation Economics, 42-49. 10.1016/j.retrec.2016.07.004

Seyrek, İ. H., \& Ata, A. (2010). Veri zarflama analizi ve veri madenciliği ile mevduat. BDDK Bankac l>k ve Finansal Piyasalar, 4(2), 67-84. https://www. bddk.org.tr/WebSitesi/turkce/Raporlar/BDDK_ Dergi/9071ibrahim.pdf 
Tavassoli , M., Farmarzi, G. R., \& Saen, R. F. (2014). Efficiency and effectiveness in airline performance using a SBM-NDEA model in the presence of shared input. Journal of Air Transport Management, 146-153. 10.1016/j.jairtraman.2013.09.001

Tetik, S. (2003). İşletme performansını belirlemede veri zarflama analizi. Celal Bayar Üniversitesi İ.̇.B.F. Dergisi, 10(2), 221-229. http://www2.bayar. edu.tr/yonetimekonomi/dergi/pdf/C10S22003/ st.pdf

Vasıgh, B., Fleming, K., \& Tacker, T. (2013). Introduction to Air Transport Economics From Theory to Applications. London: MPG Books.

Wang, W.-K., Lu, W.-M., \& Tsai, C.-J. (2011). The relationship between airline performance and corporate governance amongst US Listed companies. Journal of Air Transport Management, 148-152. 10.1016/j.jairtraman.2010.06.005
Wu, Y., He, C., \& Cao, X. (2013). The impact of environmental variables on the efficiency of Chinese and other non-Chinese airlines. Journal of Air Transport Management, 35-38. 10.1016/j.jairtraman.2013.02.004

Yolalan, R. (1993). İșletmelerarası göreli etkinlik ölçümü. Ankara: Milli prodüktivite merkezi yayınları.

Zhu, J. (2011). Airlines Performance via Two-Stage Network DEA Approach. Journal of CENTRUM Cathedra, 260-269. file:///C:/Users/user/Downloads/SSRN-id1931862.pdf 